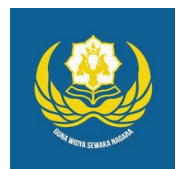

Jurnal Analogi Hukum

Journal Homepage: https://ejournal.warmadewa.ac.id/index.php/analogihukum

\title{
Pertanggungjawaban Direksi Perseroan Terbatas Yang Melakukan Perbuatan Melawan Hukum
}

\author{
Desak Made Setyarini *, Ni Luh Made Mahendrawati dan Desak Gde Dwi Arini \\ Universitas Warmadewa, Denpasar-Bali, Indonesia \\ *made.setyarini@gmail.com
}

How To Cite:

Setyarini, D, M., Mahendrawati, N, L, M., Arini, D, G, D.(2019). Pertanggungjawaban Direksi Perseroan Terbatas Yang Melakukan Perbuatan Melawan Hukum. Jurnal Analogi Hukum. 2 (1). 12-16. Doi: http://dx.doi.org/10.22225/.2.1.1608.12-16

\begin{abstract}
Directors in a limited liability company can be likened to a life for the company. The Board of Directors in carrying out their duties in managing a limited liability company has the possibility to carry out acts against the law both civil and criminal in nature. However, acts against the law can be directly carried out by the company through its organs, or vice versa, acts against the law are carried out by employees and the company is responsible. Based on this, the problem is obtained: 1) what forms of unlawful actions by the Board of Directors in managing a limited liability company (Corporation)? 2) What is the responsibility of the Directors who commit illegal acts? This research method uses normative legal research, with literature studies of primary and secondary legal materials. Based on research findings, it is known that: 1) Forms of unlawful acts carried out by directors: using company money/ wealth for personal gain, company information for personal gain, conducting related parties transactions with companies, prohibiting competition with the company 2) Directors' responsibility for illegal acts is regulated in Law No. 40 of 2007 the directors are responsible for managing the company where the management has to be done by each member of the board of directors, in good faith and full of responsibility. From this, it is necessary to optimize the implementation and supervision of the Corporation Law which substantially provides protection to business stakeholder and other public rights.
\end{abstract}

Keyword: Accountability of Directors, Limited Liability Companies, Action against the Law

\begin{abstract}
Abstrak-Direksi di dalam perseroan terbatas dapat diumpamakan sebagai nyawa bagi perseroan. Direksi dalam menjalankan tugasnya mengelola perseroan terbatas memiliki kemungkinan untuk melakukan perbuatan melawan hukum baik bersifat perdata maupun pidana. Akan tetapi, perbuatan melawan hukum itu dapat langsung dilakukan oleh perusahaan melalui organ-organnya, atau sebaliknya perbuatan melawan hukum itu dilakukan oleh pegawai dan perusahaan wajib mempertanggungjawabkan. Berdasarkan hal tersebut maka didapatlah permasalahan yakni 1) Bagaimana bentuk perbuatan melawan hukum yang dilakukan oleh Direksi di dalam mengurus perseroan terbatas? 2) Bagaimana tanggung jawab Direksi Perseroan Terbatas yang melakukan perbuatan melawan hukum? Metode penelitian ini menggunakan penelitian hukum normatif, dengan studi kepustakaan dari bahan hukum primer dan sekunder. Berdasarkan temuan penelitian diketahui bahwa: 1) Bentuk perbuatan melawan hukum yang dilakukan oleh direksi: mempergunakan uang/ kekayaan perseroan untuk kepentingan pribadi, informasi perseroan untuk kepentingan pribadi, melakukan transaksi dengan perseroan, larangan bersaing dengan perseroan 2) Pertanggungjawaban direksi atas perbuatan melawan hukum diatur dalam UU No. 40 Tahun 2007 direksi bertanggung jawab atas pengurusan perseroan dimana pengurusan itu wajib dilaksanakan setiap anggota direksi dengan itikad baik dan penuh tanggung jawab. Dari hal tersebut sebaiknya Perlu optimalisasi pelaksanaan dan pengawasan UUPT yang secara substansial memberikan perlindungan kepada pelaku bisnis dan hak-hak publik lainnya.
\end{abstract}

Kata Kunci: Pertanggungjawaban Direksi, Perseroan Terbatas, Melawan Hukum

\section{Pendahuluan}

Perseroan Terbatas mempunyai beberapa organisasi yaitu RUPS, Direksi, dan Dewan
Komisaris. Perseroan Terbatas selaku subjek hukum mandiri ialah artificial person, sesuatu yang bukan jelas atau tidak riil. Jadi Perseroan Terbatas tidak dapat bertindak sendiri. Agar 
dapat melakukan perbuatan dalam hukum, Perseroan Terbatas dijalankan oleh organisasiorganisasi yang berperan memangku Perseroan Terbatas tersebut yang memerlukan Direksi menjadi wakilnya. Bisa dikatakan bahwa perseroan terbatas tidak dapat beroperasi dan menyelenggarakan hak dan kewajibannya tanpa andil dari Direksi (Widjaja, 2008).

Direksi di dalam perseroan terbatas dapat diumpamakan sebagai nyawa bagi perseroan. Tidak diperbolehkan suatu perseroan tidak memiliki Dewan Direksi. Sebaliknya, tidak dimungkinkan adanya Direksi tanpa adanya perseroan. Kehadiran Direksi ialah untuk mengurusi perseroan sesuai dengan maksud dan tujuan perseroan beserta itikad baik dan penuh rasa tanggung jawab. oleh sebat itu kehadiran Direksi sangat penting bagi perseroan. Didalam menjalankan perseroan tidaklah hal mudah. Oleh sebab itu, supaya perseroan itu bisa berjalan sesuai dengan maksud dan tujuan pembentukan perseroan, maka untuk menjabat Direksi perlu persyaratan dan keahlian yang bagus.

Direksi ialah organisasi perseroan yang berkewajiban penuh atas pengelolaan perseroan untuk kebutuhan dan keinginan perseroan serta mewakili perseroan baik di dalam atau di luar pengadilan berpatutan dengan ketentuan Anggaran Dasar.

Terpaut pada perbuatan melawan hukum, korporasi atau perseroan jadi subjek hukum dapat melaksanakan perbuatan melawan hukum baik bersifat perdata atau pidana (civil and criminal wrongs). Umumnya pengurus yang harus bertanggung jawab atas aksi melawan hukum tersebut. Melainkan, aksi melawan hukum itu bias langsung dilaksanakan oleh perusahaan melalui organ-organnya, atau sebaliknya perangai melawan hukum itu dilakukan oleh karyawan perusahaan dan perusahaan mempertanggungjawabkannya.

Perseroan selaku Badan Hukum yang dibebani hak dan tanggung jawab sebagaimana manusia pada umumnya. Didalam Perseroan Terbatas terdapat 3 (tiga) organ, yakni RUPS, Direksi dan Komisaris. Direksi ialah satusatunya organ dalam perseroan yang mengelola kewajiban pengurusan perseroan. Ada 2 (dua) fungsi utama mengenai direksi suatu perseroan, yakni fungsi manajemen, didalam artian direksi melaksanakan kewajiban memimpin perusahaan dan fungsi representasi, didalam arti direksi mewakili perusahaan di dalam maupun di luar pengadilan (Fuady, 2002).
Berdasarkan rumusan Pasal 92 ayat (1) UUPT bisa dikatakan jika organ perseroan yang berfungsi menjalankan pengurusan perseroan ialah direksi. Setiap bagian anggota direksi harus menggunakan itikad baik dan penuh rasa tanggung jawab melakukan kewajiban untuk keperluan dan usaha dalam perseroan. "Hal ini membawa konsekuensi hukum bahwa setiap anggota direksi bertanggung jawab secara pribadi apabila yang bersangkutan bersalah atau lalai menjalankan tugasnya untuk kepentingan dan usaha perseroan" (Widjaja, 2008).

Aktivitas direksi dalam mengatur perseroan tidak hanya bersumber pada aturan yang ada di UUPT dan pada anggaran dasar perseroan yang berkaitan. Aktivitas direksi pun harus memandang ketetapan fiduciary duty dan business judgment rule. Fiduciary duty adalah pendelegasian kewenangan oleh perseroan pada direksi untuk mengurusi PT, meskipun business judgment rule merupakan doktrin guna mencegah ketidakmampuan dari direksi PT yang diakibatkan oleh adanya keterbatasan pada manusia.

Dari uraian latar belakang tersebut, maka terdapat 2 (dua) permasalahan yang ditemukan dalam topik tersebut, yaitu: 1) Bagaimana bentuk perbuatan melawan hukum yang dilakukan oleh Direksi dalam mengurus perseroan terbatas? dan 2. Bagaimana tanggung jawab Direksi Perseroan Terbatas yang melakukan perbuatan melawan hukum?

\section{Metode}

Metode penelitian menjabarkan perolehan informasi dan data dalam penelitian ini yang diawali dengan pencarian, pengumpulan dan analisis bahan hukum yang sifatnya ilmiah. Perlu sebuah metode dalam penelitian karena pada dasarnya merupakan operasinalisasi dari metode keilmuan untuk menjabarkan analisis dalam langkah-langkah sitematis dan konsisten. Adapun metode penelitian dijabarkan sebagai berikut:

Tipe penelitian ini tergolong penelitian hukum normatif, pendapat Soejono Soekanto bahwa penelitain tersebut merupakan penelitian terhadap asas-asas hukum, penelitian terhadap sistematika hukum dan penelitian terhadap sinkronisasi hukum.

Pada penelitian ini, menggunakan bahan hukum yang diperoleh dari penelitian kepustakaan (library research), yaitu : 1) Bahan Hukum Primer meliputi Undang-Undang Dasar Negara Republik Indonesia Tahun 1945, Kitab Undang-Undang Hukum Perdata,Undang- 
Undang Nomor 40 Tahun 2007 tentang Perseroan Terbatas. 2) Bahan Hukum Sekunder meliputi literatur, artikel, hasil-hasil penelitian, dan lain-lain

Pengumpulan bahan hukum dilakukan dengan cara memeriksa, mengumpulkan dan menelusuri dokumen kepustakaan dengan pencatatan yang kemudian dijadikan bahan sebagai analisis permasalahan menggunakan argumentasi berdasarkan logika deduktif dan induktif dituangkan secara deskriptif dalam bentuk skripsi

\section{Hasil Penelitian dan Pembahasan}

\section{Bentuk Perbuatan Melawan Hukum Yang Dilakukan Oleh Direksi Dalam Mengurus Perseroan Terbatas}

Secara sederhana dapat dikatakan perbuatan melawan hukum adalah suatu perbuatan secara nyata melanggar peraturan perundang-undangan yang berlaku. Artinya, setiap orang atau pelaku usaha melanggar ketentuan peraturan perundang-undangan yang berlaku dapat dikatakan suatu perbuatan melawan hukum. Pada pasal 1365 KUHPerdata ditentukan, maka tindakan melawan hukum adalah setiap perbuatan yang membuat penderitaan pada orang lain, dan orang yang mengakibatkan kerugian kepada orang lain, dan orang yang mengakibatkan kerugian diwajibkan memberikan ganti rugi kepada orang yang mengalami kerugian tersebut (Silalahi, 2005).

Unsur perbuaan melawan hukum ialah sebagai berikut:

Adanya tindakan/ perbuatan, yang disebut pada tindakan/ perbuatan ini adalah yang bersifat positif atau bersifat negative, berartia setiap perangai berbuat atau tidak berbuat;

Tindakan/ Perbuatan itu melanggar hukum;

Adanya kehilangan/ kerugian;

Adanya hubungan sebab akibat tindakan melawan hukum itu sendiri dengan mengakibatkan kerugian;

\section{Adanya kekeliruan/ kesalahan.}

Dialam perbuatan/ tindakan melawan hukum, gugatan ganti rugi berpatutan pada ketetapan Pasall 1365 KUHPerdata,tidak usah untuk mengatakan ganti rugi bagaimana tatanannya, tidak usah mendetail dan patut menggantikan kerugian idiil. Bentuk ganti kerugian perbuatan melawan hukum:
8Ganti rugi didalam rupa uang kepada mennyusutnya asset harta kekayaan akibat adanya tindakan/perbuatan melawan hukum (Ganti kerugian Materiil, dan paling banyak dituntut didalam praktik).

Perbaikan didalam keadaan seperti semula.

Pengembalian biaya-biaya demi pemulihan didalam keadaan seperti semula.

Penggantian kerugian uang atas adanya penderitaan dan kesusahan seseorang/ nama yang baik tercemar atas karena tindakan/ perbuatan melanggar hukum (penggantian kerugian Immateriil).

Yang harus dihindari oleh anggota Direksi antara lain:

Tidak memakai uang dan kekayaan dari perseroan untuk keperluan pribadi. bila dilanggar akan mengakibatkan kerugian pada perseroan.

Menggunakan informasi perseroan demi kepentingan pribadi. Tindakan ini digolongkan berbuat pelanggaran pada kewajiban yang diyakini.

Menggunakan posisi untuk mendapatkan keuntungan pribadi semacam terima sogokan.

Menghalangi atau merebut sebahagian atas keuntungan perseroan untuk kepentingan pribadi. Tindakan tersebut menggambarkan perbuatan yang menyembunyikan keuntungan dari anggota direksi yang berkaitan.

Membuat transaksi pada perseroan.

Pantangan bersaing pada perseroan.

Contoh kasus perbuatan melawan hukum yang dilakukan oleh Direksi dalam mengurus perseroan terbatas : Kasus korupsi pengucuran kredit usaha kecil dan menengah yang melibatkan PT Bahana Pembinaan Usaha Indonesia (BPUI) Sudjiono Timan menjabat/ berkedudukan selaku Direktur PT Bahana Pembinaan Usaha Indonesia (BPUI), yaitu sebuah perseroan sekuritas nasional didirikan untuk menopang para pengusaha kecil maupun menengah. Namun, dalam memberikan bantuan modal tersebut ternyata Sudjiono Timan selaku Direktur PT. Bahana tersebut beserta dengan direksi yang lain, yaitu Hadi Rusli, Witjaksono Abadiman, Haria Suprobo, dantelah melakukan penyimpangan dalam pemberian modal kepada pengusaha kecil dan menengah.

Penyimpangan yang dilakukan adalah menyelewengkan dana PT Bahana atas 
pengucuran dana pada perusahaan tidak nyata kinerjanya. Selain itu, dalam pengucuran dana tersebut juga tidak didukung dengan adanya perjanjian yang jelas antara PT Bahana dan perusahaan tersebut. Diantaranya yang bermasalah adalah Kredit Asia finance Ltd., sebuah perusahaan yang berbasis di Hongkong, tetapi dijalankan di Jakarta.

Total Kerugian negara akibat perbuatan menyimpang yang dilakukan oleh Sudjono Timan dalam memberikan kredit bukan kepada usaha kecil dan menengah mencapai $\mathrm{Rp}$ 2,2 triliun. Dalam persidangan tahap pertama di Pengadilan Negeri Jakarta Selatan, Sudjino Tirman diputus bebas oleh pengadilan, dengan pertimbangan hukum yang pada dasarnya menyatakan perkara ini murni perdata bukan perkara pidana. Dan atas putusan bebas tersebut maka jaksa penuntut umum telah mengajukan upaya hukum kasasi ke Mahkamah Agung RI.

Ternyata, hakim tingkat kasasi yang memeriksa dan mengadili perkara Sudjino Timan ini berpendapat lain sehingga mengurungkan putusan Pengadilan Negeri Jakarta Selatan pada tanggal 25 November 2002 dan mengadili sendiri dengan menjatuhkan hukuman kepada Sudjino Timan selama 15 tahun kurungan lalu mengganti uang sebesar Rp 369 miliar oleh Mahkamah Agung RI karena terbukti melakukan tindakan korupsi (Yunara, 2005).

Pasal 1 angka 5 UUPT, menentukan bahwa :

Direksi ialah organ Perseroan yang berwenang dan bertanggung jawab seluruhnya atas manajemen Perseroan untuk keperluan Perseroan, sesuai pada maksud dan tujuan dari Perseroan beserta mewakili Perseroan, baik dalam ataupun diluar pengadilan selaras pada ketentuan anggaran dasar.

Pada pemahaman termaktub, dari prinsipnya termuat 2 (dua) kewenangan utama Direksi, yakni mengurusi dan mewakili Perseroan Terbatas. Wewenang Direksi itu diberikan dan dibatasi UUPT beserta aturan perundang-undangan lainnya yang terkait sasaran dan tujuan PT, anggaran dasar PT. Implementasi kewajiban Direksi bagi Perseroan secara rutin dilengkapi serta wewenang yang ditetapkan dalam UUPT. Hal ini sejalan pada anggapan jika Direksi memerlukan kewenangannya supaya dapat menepati kewajiban dan melaksanakan fungsi-fungsinya (Fuady, 2002).
Tanggung Jawab Direksi Perseroan Terbatas Yang Melakukan Perbuatan Melawan Hukum

Setiap jabatan mendapat tugas, kewajiban, dan wewenang. Sudah pasti tugas, kewajiban dan kewenangan itu harus dilaksanakan dengan baik. Bila tugas serta tanggung jawab tersebut dilalaikan ataupun wewenang jabatan disalahgunakan, kemudian membawa efek pada aparat yang melakukannya. Aparat itu mesti bertanggung jawab pada kelalaian dan penyelewengan kekuasaannya. Begitu juga perihal pada kedudukan anggota Direksi perseroan (Sjahdeini, 2001).

Di dalam hukum perseroan, dikenal pertanggungjawaban perseroan. Artinya bahwa setiap konsekuwensi yuridis pada sikap perseroan, baik ataupun buruk akan dipikul sendiri pada perseroan itu. UUPT menentukan dan mengatur luasnya kekuasaan dan kewenangan seorang Direksi. Dengan kekuasaannya yang sangat besar ada kemungkinan akan merugikan perseroan. Namun dalam UUPT tidak ada diatur dengan tegas sebagaimana kalau alih-alih pengurus membuat perbuatan yang melebihi atau berlawanan dengan anggaran dasar.

Sudah merupakan asas yang umum, apabila pengurus membuat tindakan yang melawati batas kewenangan ataupun berlawanan pada anggaran dasar, dan tindakan itu dipandang semata-mata bagi prilaku pribadi pada pengurus, dan tidak perbuatan dari perusahaan. Konsekwensinya perseroan tidak betanggung jawab, melainkan hanya jadi tanggung jawab pribadi sepenuhnya oleh pengurus (Prasetya, 2004). Hal ini berarti bahwa PT tidak terikat atas semua tindakan organnya yang bertindak di luar batas kewenangan.

Direksi dapat digugat dengan perbuatan melawan hukum apabila merugikan. upayaupaya hukum tersebut antara lain:

Menganjurkan gugatan lewat PN pada anggota Direksi ataupun anggota Dewan Komisaris lantaran pelanggaran ataupun kelalaiannya mengakibatkan kerugian PT.

Mengajukan gugatan melalui Pengadilan Negeri karena Perseroan Terbatas dianggsip tidak adil dan tanpa alasan wajar dalam mengambil keputusan baik dalam RUPS, maupun dalam forum Direksi, dan atau Dewan Komisaris.

Mengajukan pemeriksaan perseroan pada Pengadilan Negeri atas dugaan perbuatan melawan hukum. 
Direksi yang lalai atau salah dalam mengurus perseroan dan mengakibatkan kerugian harus bertanggung jawab. empat cara untuk lepas dari tanggung jawab, yaitu noodweer atau pembelaan diri, overmacht atau keadaan memaksa, noodtoestand dan pembayaran ganti rugi. Keempat hal ini disebut sebagai alasan-alasan pembenar (rechtvaardigingsgrond) untuk menghilangkan sifat melawan hukum dari satu perbuatan. Noohveer atau pembelaan diri, Direksi dapat menggunakan Pasal 97 ayat 5 UUPT.

Pembelaan diri atau noodweer merupakan pembuktian bahwa seseorang sudah membuat tugasnya penuh "itikad baik" atau "hati-hati". Overmacht atau keadaan memaksa dapat bersifat mutlak (absolute) atau tak mutlak (relative). Kondisi memaksa yang bersifat mutlak adalah bahwa setiap orang dalam keadaan tersebut dapat dipastikan akan terpaksa melakukan perbuatan melawan hukum. Untuk kondisi memaksa relatif, timbul bila seorang membuat tindakan melawan hukum yang dalam kondisi tertentu yang sebetulnya dapat dihindari, tetapi karena kedudukannya perbuatan melawan hukum terpaksa dilakukan. Dalam ha1 ini kewajibannya untuk menghindari dianggap hilang. Apabila Direksi mengambil kebijakan tertentu karena keadaan terpaksa baik mutlak maupun relatif, dan tidak ada jalan lain, maka Direksi harus dibebaskan dari tanggung jawab.

Noodtoestand merupakan tindakan yang bersifat penyelamatan akan kepentingan tertentu dengan cara melakukan pelanggaran hukum. Dalam ha1 ini tidak ada kewajiban mengganti rugi, karena perbuatan tersebut tidak onrechtmachtig. Upaya penyelamatan disini adalah penyelamatan perseroan dari kerugian yang lebih besar. Secara pribadi, mengenai Piercing The Corporate Veil yaitu: Bagi perseroan yang berbentuk Badan Hukum, lalu menurut hukum dari prinsipnya harta benda itu terbagi dari harta pendiri ataupun pemiliknya, dengan itu tanggungjawab menurut hukum pula dibedakan dari harta benda pribadi pemilik perseroan tersebut. Jika suatu PT memulai perbuatan pada pihak lain, yang menerima konsekuen ialah perseroan itu dan bertanggung jawabnya sebatas harta benda yang dimiliki. Menurut doktrin ini, didalam situasi tersendiri pemegang saham boleh bertanggung jawab pada perseroan atau pemegang sahamnya tidak bisa disita maupun digugat untuk untuk diberatkan pada tanggungjawab PT itu. Pendapat tersebut tidak berlaku ketika direksi dalam melaksanakan perusahaan telah melanggar atau melampaui batas kewenangan sehingga menimbulkan kerugian terhadap perseroan sendiri maupun pihak diluar perseroan karena yang akan bertanggungjawab atas kerugian tersebut adalah direksi secara pribadi baik berupa materi maupun immaterial.

\section{Simpulan}

Dari hasil penelitian yang telah diuraikan, maka dapat ditarik kesimpulan yaitu : 1) Bentuk -bentuk perbuatan melawan hukum yang dilakukan oleh direksi dalam mengurus perseroan adalah: mempergunakan aset,uang dan kekayaan dari perseroan untuk keperluan pribadi (korupsi). menerapkan informasi perseroan untuk keperluan pribadi, membuat bisnis dan transaksi dengan perseroan, pembatasan bersaing pada perseroan. 2) Pertanggungjawaban direksi akibat perbuatan dari melawan hukum yang dilakukan didalam mengelola perseroan ditetapkan didalam pasal 97 ayat (1) dan (2) UU No. 40 Tahun 2007 yang menentukan bahwa direksi berkewajiban pada pengelolaan perseroan dimana pengurusan itu harus dilakukan setiap anggota direksi serta pada itikad baik dan penuh rasa tanggung jawab.

\section{Daftar Pustaka}

Fuady, M. (2002). Doktrin-doktrin Modern dalam Corporate Law dan Eksistensinya dalam Hukum Indonesia. Bandung: Citra Aditya Bakti.

Prasetya, R. (2004). Kedudukan Mandiri Perseroan Terbatas. Bandung: Citra Aditya Bakti.

Silalahi, J. M. U. (2005). Badan Hukum Organisasi Perusahaan. Jakarta: Iblam.

Sjahdeini, S. R. (2001). Tanggung Jawab Pribadi Direksi dan Komisaris. Jurnal Hukum Bisnis. Jakarta.

Widjaja, G. (2008). 150 Tanya Jawab tentang Perseroan Terbatas. Jakarta: Forum Sahabat.

Yunara, E. (2005). Korupsi dan Pertanggungjawaban Pidana Korporasi Berikut Studi Kasus. Bandung: Citra Aditya Bakti.

Kitab Undang-Undang Hukum Perdata.

Undang-Undang Dasar Negara Republik Indonesia Tahun 1945.

Undang-Undang Nomor 40 Tahun 2007 tentang Perseroan Terbatas. 